УДК 681.2.082

С. Ф. Петренко ${ }^{1}$, д.m.н., професор

НПК ТОВ «ЛИЛЕЯ», Київ, Україна

О. Г. Новаковський ${ }^{1}$,

В. С. Антонюк ${ }^{1}$, д.m.н., професор

Є. В. Скорина ${ }^{2}$,

Ю. Ю. Бондаренко ${ }^{2}$, к.т.н., дочент

${ }^{1}$ Національний технічний університет України

«Київський політехнічний інститут імені Ігоря Сікорського»

проспект Перемоги, 37, Київ, 03056, Україна

${ }^{2}$ Черкаський державний технологічний університет

бульвар Шевченка, 460, Черкаси, 18006, Україна

\title{
ОСОБЛИВОСТІ ПРОВЕДЕННЯ ДОСЛІДЖЕНЬ МІКРОГЕОМЕТРІЇ ТА ПОВЕРХНЕВИХ ВЛАСТИВОСТЕЙ ДІЕЛЕКТРИЧНИХ МАТЕРІАЛІВ ДЛЯ МІКРО- І НАНОЕЛЕКТРОНІКИ
}

У статті коротко розглянуті особливості проведення дослідження мікрогеометрії $і$ поверхневих властивостей діелектричних матеріалів для мікро- $і$ наноелектроніки із застосуванням методу АСМ. Показано переваги та обмеження застосування иього методу для дослідження поверхні і поверхневих властивостей діелектриків.

Ключові слова: мікрогеометрія, діелектрик, мікроелектроніка, наноелектроніка, атомно-силова мікроскопія.

Актуальність. Сучасні тенденції розвитку технологій виготовлення компонентів і пристроїв комп'ютерних мікросистем, які знаходять широке застосування як для наукових досліджень, так і в прикладній практиці, спрямовані в бік мініатюризації таких пристроїв аж до нанометричних розмірів. При цьому основною вимогою до таких технологій залишається дотримання високої ефективності і надійності виготовлених елементів комп'ютерних систем. Проте реалізація цього завдання неможлива без сучасних засобів i методів дослідження мікрогеометрії, механічних і фізичних властивостей поверхні матеріалів, з яких виготовлені ці елементи.

Як показав аналіз літературних та інформаційних джерел Інтернет [1-5], на сьогодні не існує універсального неруйнівного методу дослідження стану поверхні та іï фізикомеханічних властивостей, який мав би високу точність вимірювання і контролю цих параметрів і в той же час високу продуктивність i оперативність вимірювання.

Серед найбільш поширених методів дослідження поверхні (рис. 1) необхідно виділити мікроскопічні методи дослідження як такі, що разом з високими точністю, роздільною здатністю (близько $10^{-8} \ldots 10^{-10} \mathrm{M}$ ) і продуктивністю (час отримання одного знімка топогра- ми поверхні - від декількох секунд до декількох хвилин) мають високу збіжність і достовірність результатів дослідження, а також дають можливість не тільки вимірювати мікрогеометрію поверхні, але й отримувати дані щодо хімічного складу, електричних і магнітних властивостей матеріалів, будови й структури їх поверхні.

Серед існуючих методів дослідження поверхні найбільш прогресивним та універсальним вважається метод атомно-силової мікроскопії (ACM). АCM не вимагає спеціальної підготовки досліджуваного зразка, при цьому метод $\epsilon$ неруйнівним, має високу точність (до одиниць ангстрем) і чутливість дослідження $\left(\approx 10^{-8} \mathrm{H}\right)$.

Значний науковий внесок у розвиток новітніх методів дослідження в галузях точного приладобудуванні, зокрема у метод атомно-силової мікроскопії, зробили багато вітчизняних i зарубіжних вчених, зокрема: Биков В. А., Бінніг Г., Брушан Б., Гербер К., Карбівський В. Л., Куейт К., Міронов В. Л., Рожицький М. М., Рорер Х., Свірідьонок А. І., Снежко Д. В., Чижик С. А. та інші [6-10]; а вирішенню задач підвищення точності вимірювання нанорельєфу та механічних характеристик поверхонь методом атомно-силової мікроскопії присвячені роботи: Дуба С. М., 
Жавнерка Г. К., Занавєскіна М. Л., Кузнецової Т. А., Курільонка М. А., Литвин П. М.,
Магонова С. М., Свірідової О. В., Суслова А. А., Толстіхіної А. Л. та інших [11-15].

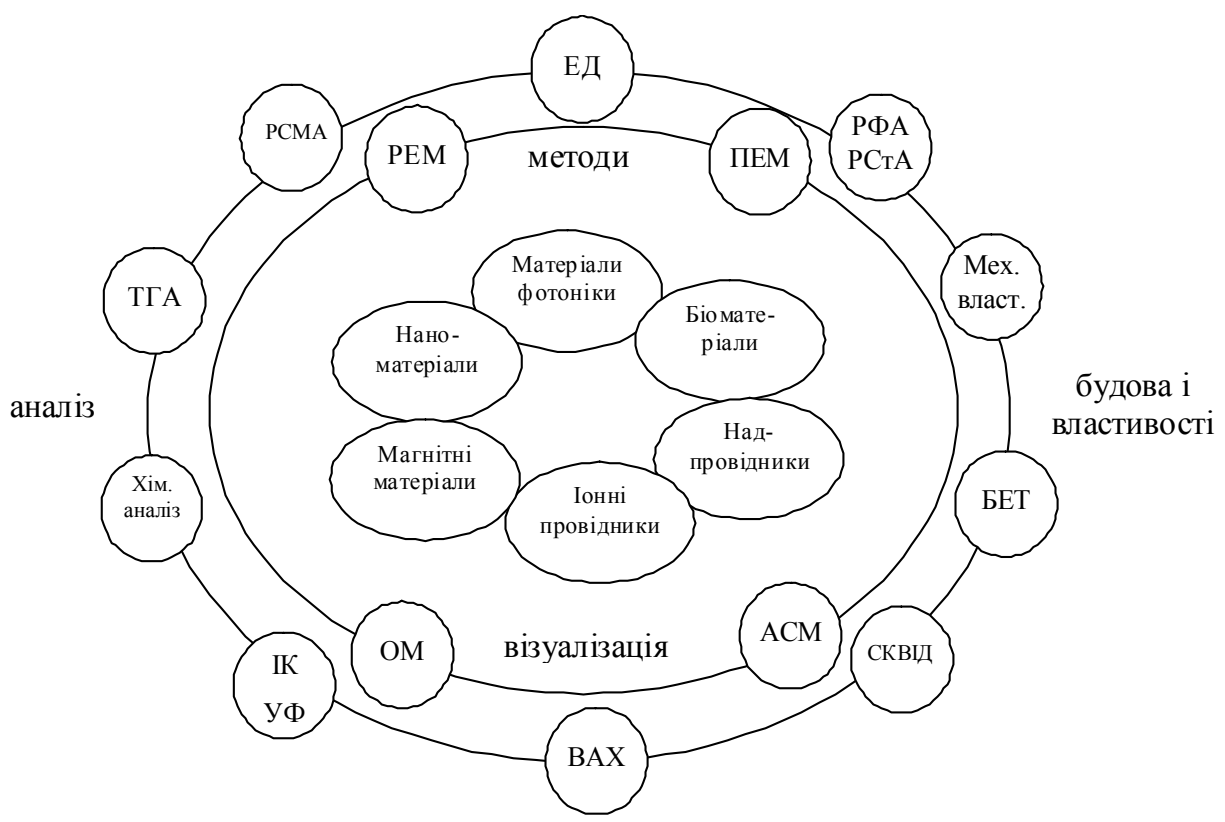

Рис. 1. Методи дослідження сучасних матеріалів:

ОМ - оптична мікроскопія, РЕМ - растрова електронна мікроскопія, ПЕМ - електронна мікроскопія, що працює на просвітлення, АСМ - атомно-силова мікроскопія, РСМА - рентгеноспектральний мікроаналіз,

РФА - рентгенофазовий аналіз, РСтА - рентгеноструктурний аналіз, ЕД - дифракція електронів,

ІЧ - спектроскопія в інфрачервоній області, УФ - спектроскопія у видимій і ультрафіолетовій областях, ТГА - термічний аналіз, ВАХ - визначення вольт-амперних характеристик, СКВІД - вимірювання магнітних властивостей, БЕТ - визначення площі поверхні

Проте, незважаючи на бурхливий розвиток методу, проблема проведення дослідження мікрогеометрії і поверхневих властивостей діелектричних матеріалів із застосуванням методу атомно-силової мікроскопії $\epsilon$ актуальною.

Метою статті $\epsilon$ встановлення особливостей проведення дослідження мікрогеометрії та поверхневих властивостей діелектричних матеріалів методом атомно-силової мікроскопії, а також переваг і обмежень використання цього методу при дослідженні діелектричних матеріалів.

Принцип роботи та особливості проведення досліджень методом атомносилової мікроскопії.

Принцип роботи атомно-силового мікроскопа полягає у взаємодії вимірювального інструмента АCM із досліджуваною поверхнею за рахунок міжмолекулярних сил притягування і відштовхування [16, 17]. У міру наближення зонда до досліджуваної поверхні атоми вістря зонда і поверхні починають при- тягуватися. Сила притягування буде збільшуватися доти, поки атоми не будуть настільки близькі, що їх електронні оболонки почнуть відштовхуватися під дією електростатичних сил. Згодом сили притягування і сили електростатичного відштовхування врівноважуються на відстані між зондом і поверхнею близько двох ангстрем. У цей момент сумарна сила взаємодії стає позитивною (силою відштовхування), що означає факт міжатомного контакту.

Подальше підведення зонду АСМ до досліджуваної поверхні веде до збільшення сили відштовхування внаслідок взаємодії ядер атомів об“єктів взаємодії. Таке збільшення сили відштовхування продовжується до моменту фізичного контакту зонду з поверхнею.

Розглянемо функціональну схему роботи атомно-силового мікроскопу (рис. 2) [18], а також проведемо дослідження принципів дії основних елементів та функціональних вузлів цих приладів. 


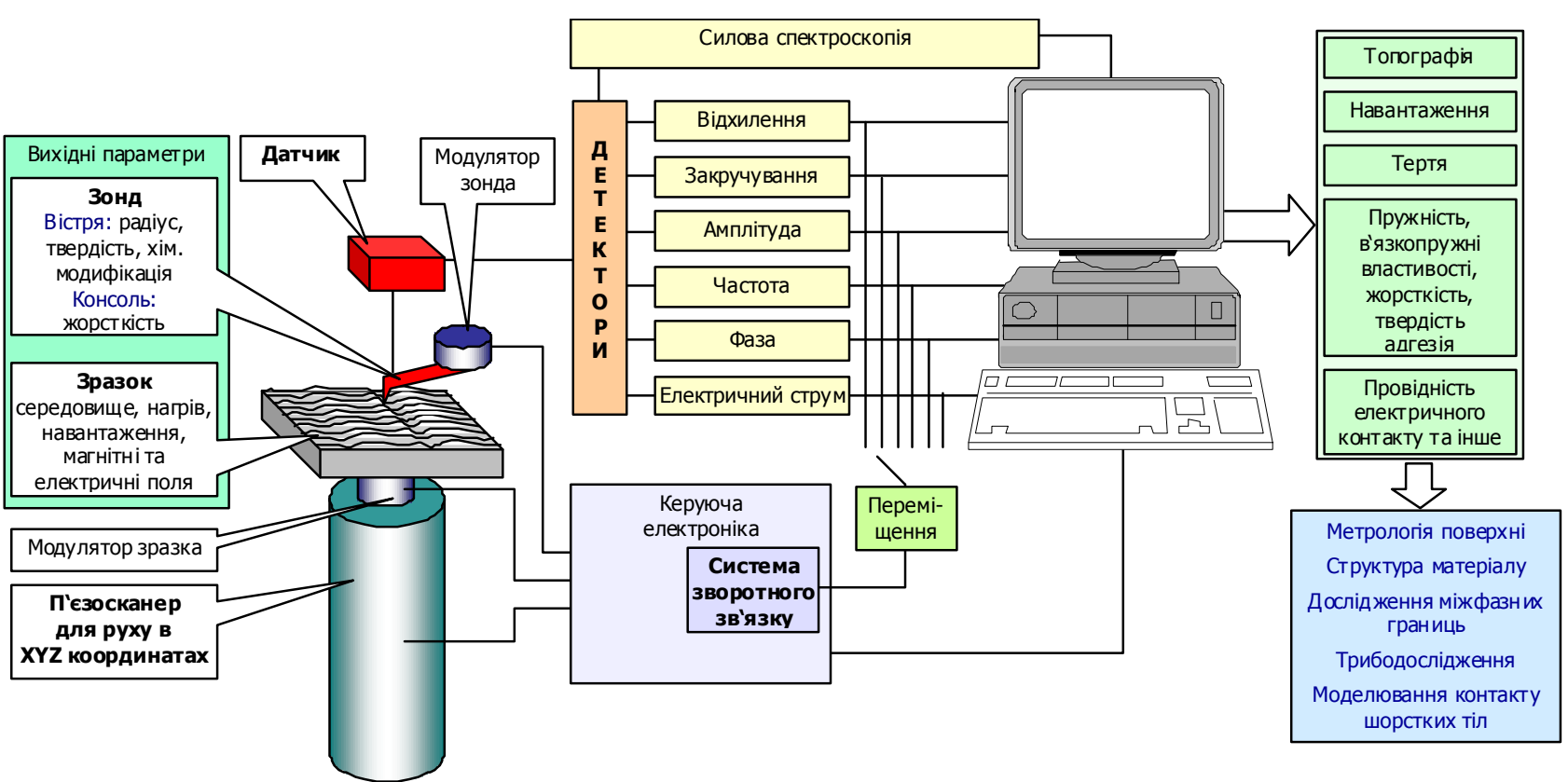

Рис. 2. Функціональна схема атомно-силового мікроскопу [18]

Вимірювальною системою АСМ є консоль, розташована на п'єзоелектричному чипі, на вільному кінці якої розташований зонд. У міру наближення зонда до досліджуваної поверхні між ними виникають сили взаємодії, які залежать від того, наскільки близько знаходиться досліджувана поверхня. Використання вимірювального блока дає змогу відстежити мікрогеометрію і механічні властивості поверхонь 3 високою точністю і чутливістю, що стає можливим шляхом використання сучасних методів мікроелектроніки i мікрооптики, проте останні обмежені технічними характеристиками матеріалів, 3 яких виготовлена вимірювальна система.

Залежно від відстані між досліджуваним зразком і зондом розрізняють такі режими роботи ACМ: контактний режим, безконтактний режим, а також напівконтактний режим («tape-mode»), що $\epsilon$ проміжним режимом між першими двома.

При контактному режимі (відомому також як режим відштовхування) вістря зонда приходить в контакт із досліджуваною поверхнею. Сила відштовхування врівноважує практично будь-яку силу, яка намагатиметься зблизити атоми. Для АСМ це означає, що, якщо вимірювальна консоль притискає вістря зонда до досліджуваної поверхні, то скоріше відбудеться згинання консолі, аніж цій силі вдасться наблизити зонд до поверхні.

Для контактного режиму сила відштовхування врівноважується капілярними силами (які виникають при дослідженні зразка на повітрі). Рельєф досліджуваної поверхні формується, як правило, або в режимі постійної висоти, або в режимі постійної сили. У першому випадку консоль рухається в горизонтальній площині, а значення відштовхування реєструється в кожній точці. В іншому випадку, за допомогою системи зворотного зв'язку, на постійному рівні підтримуються відхилення консолі, тобто сила взаємодії його із зразком. Переміщення зразка або консолі здійснюється за допомогою п'єзоелектричного маніпулятора.

У безконтактному режимі, також відомому як режим притягування, АСМ відстежує сили Ван-дер-Ваальса між вістрям зонда i зразком. Відстань між вістрям і зразком в цьому режимі становить близько 5-10 нм. На такій відстані електронні орбіталі атомів вістря зонда починають синхронізуватися 3 електронними орбіталями атомів зразка. В результаті виникає слабке притягування, оскільки в будь-який момент атоми зонда і зразка поляризуються в одному напрямку. У вільному просторі ці атоми будуть наближатися доти, поки сильне електричне відштовхування, описане раніше, не стане переважаючим. У безконтактному режимі роботи АCM сумарна сила між зондом і зразком становить приблизно $10^{-12} \mathrm{H}$. Це $\epsilon$ перевагою для дослідження м'яких і пружних зразків, а також зразків із кремнію, які не забруднюються при контакті 3 зондом. 
У напівконтактному режимі система АСМ моделює механічні коливання консолі на частоті, близькій до резонансної (30300 кГц), з амплітудою в декілька нанометрів. Величина резонансної частоти залежить від зовнішньої прикладеної сили, і тому в процесі наближення вістря зонда до поверхні зразка частота змінюється, оскільки при цьому змінюється сила Ван-дер-Ваальса. Відштовхуюча сила стабілізує пружну реакцію консолі і збільшує резонансну частоту, тоді як дія сил притягування - зменшує резонансну частоту. При роботі в напівконтактному режимі система зворотного зв'язку переміщує пристрій вгору та вниз, зберігаючи амплітуду або резонансну частоту консолі постійною.

Особливості режимів, їх переваги та недоліки наведені в табл. 1.

Таблиця 1

Порівняння основних режимів роботи АСМ

\begin{tabular}{|c|c|c|c|}
\hline \multicolumn{2}{|c|}{$\begin{array}{r}\text { Режим } \\
\text { роботи АСМ }\end{array}$} & Статичний & Динамічний \\
\hline \multirow{2}{*}{ Контактний } & + & $\begin{array}{l}\text { Високий латеральний дозвіл. } \\
\text { Можливість визначення взаєм- } \\
\text { ної деформації в системі «вістря } \\
\text { - поверхня» }\end{array}$ & $\begin{array}{l}\text { Можливість визначення площі } \\
\text { контакту і модуля пружності. Ви- } \\
\text { сокий силовий дозвіл }\left(\sim 10^{-12} \mathrm{H}\right) \text {. } \\
\text { Незначний температурний дрейф }\end{array}$ \\
\hline & - & $\begin{array}{l}\text { Висока ймовірність пошкоджен- } \\
\text { ня поверхні. Низький силовий } \\
\text { дозвіл }\left(\sim 10^{-9} \mathrm{H}\right) \text {. Схильність до } \\
\text { температурного дрейфу }\end{array}$ & $\begin{array}{l}\text { Висока ймовірність пошкодження } \\
\text { поверхні. Модуляція порушує } \\
\text { адгезійну взаємодію між вістрям і } \\
\text { поверхнею }\end{array}$ \\
\hline \multirow{2}{*}{ Безконтактний } & + & $\begin{array}{l}\text { Робота без пошкодження повер- } \\
\text { хні }\end{array}$ & $\begin{array}{l}\text { Робота без пошкодження поверх- } \\
\text { ні. Високий силовий дозвіл. Не-- } \\
\text { значний температурний дрейф }\end{array}$ \\
\hline & - & $\begin{array}{l}\text { Низький силовий і просторовий } \\
\text { дозвіл. Схильність до темпера- } \\
\text { турного дрейфу }\end{array}$ & $\begin{array}{l}\text { Низька просторова роздільна зда- } \\
\text { тність }\left(\sim 10^{-9} \mathrm{M}\right)\end{array}$ \\
\hline
\end{tabular}

У той же час особливістю атомносилового мікроскопа $є$ не тільки можливість дослідження нанопрофілю і топографії поверхні. АСМ також може використовуватися для різних фізичних і механічних вимірювань поверхневих властивостей на нанорівні. Детальніша інформація про вимірювання, які можуть проводитися за допомогою АCM, наведена нижче.

Дослідження топології поверхні. Дослідження наногеометрії поверхні - найбільш затребуваний метод АСМ. Разом з високою роздільною здатністю він дозволяе відобразити мікрорельєф поверхні з точністю по висоті близько 0,1-0,2 нм.

У процесі реалізації методу модуляції сили одночасно зі скануванням зразка в режимі постійної висоти зонд (або зразок) здійснює вертикальні періодичні коливання. У момент торкання зондом поверхні консоль деформується пропорційно нерівностям поверхні зразка. При цьому тиск зонда на поверхню зразка не залишається постійним, а містить періодичну (зазвичай, синусоїдальну) компоненту. Відповідно до локальної жорсткості зразка величина відповідних нерівностей буде змінюватися в процесі сканування. На жорстких ділянках поверхні зразка поглиблення, пов'язані $з$ деформаційним впливом зонда, будуть менш виразними, ніж на м'яких ділянках. При цьому, відстеження рельєфу поверхні зразка проводиться з використанням усередненого вигину консолі в системі зворотного зв'язку.

Серед обмежень методу АСМ в дослідженні топології поверхні слід зазначити високу чутливість методу до змін фізичних параметрів досліджуваного зразка: його хімічного складу, твердості, адгезії, що ускладнює отримання та інтерпретацію даних топографії для ряду матеріалів. Ще одна проблема, яка обмежує використання цього методу, - артефакти на поверхні зразка при його дослідженні в динамічному режимі і низька збіжність 
вимірювань в результаті зношуваності зонда в контактному режимі. Також слід відмітити таку не вирішену досі проблему, як неточність та «тремор» зображення поверхні при скануванні ділянок, менших за 1 нм (рис. 3), що пов'язано з температурним дрейфом, мікровібрацією навколишнього середовища i механічною інерцією самої системи.
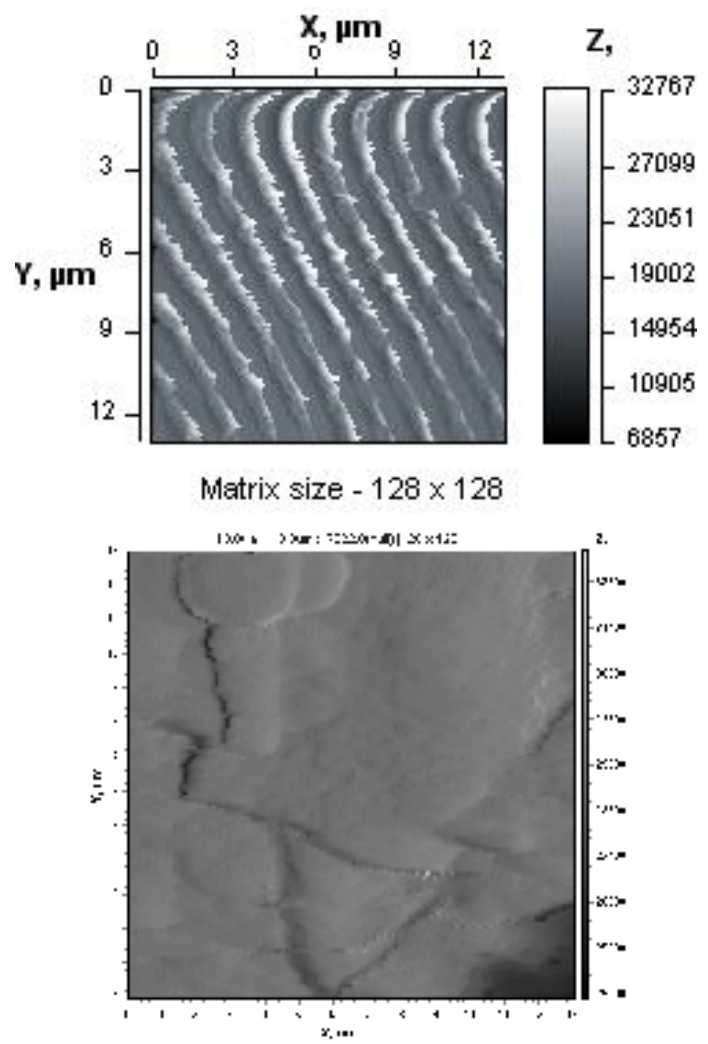

Рис. 3. Топограма поверхні ділянки дифракційної решітки, сформованої на оптичному склі К8 методом низькоенергетичної електроннопроменевої мікрообробки (вгорі) і ділянки поверхні кремнісвої пластини під вироби мікроелектроніки після хімічного травлення (знизу). На профілі дифракційної решітки чітко простежуються сліди «тремору» внаслідок дії мікровібрацій у приміщенні, де експлуатується атомно-силовий мікроскоп

Механічні вимірювання. Динамічна силова і латеральна силова спектроскопія, які можуть бути реалізовані в методі АСМ, дозволяють отримувати дані про силову і молекулярну взаємодію між зондом АСМ і досліджуваною поверхнею (рис. 4).

Використання цих методів відкриває нові перспективи при дослідженні розподілу сил тертя між двома поверхнями, що труться, в різноманітних мікроелектромеханічних пристроях і системах [18, 19].
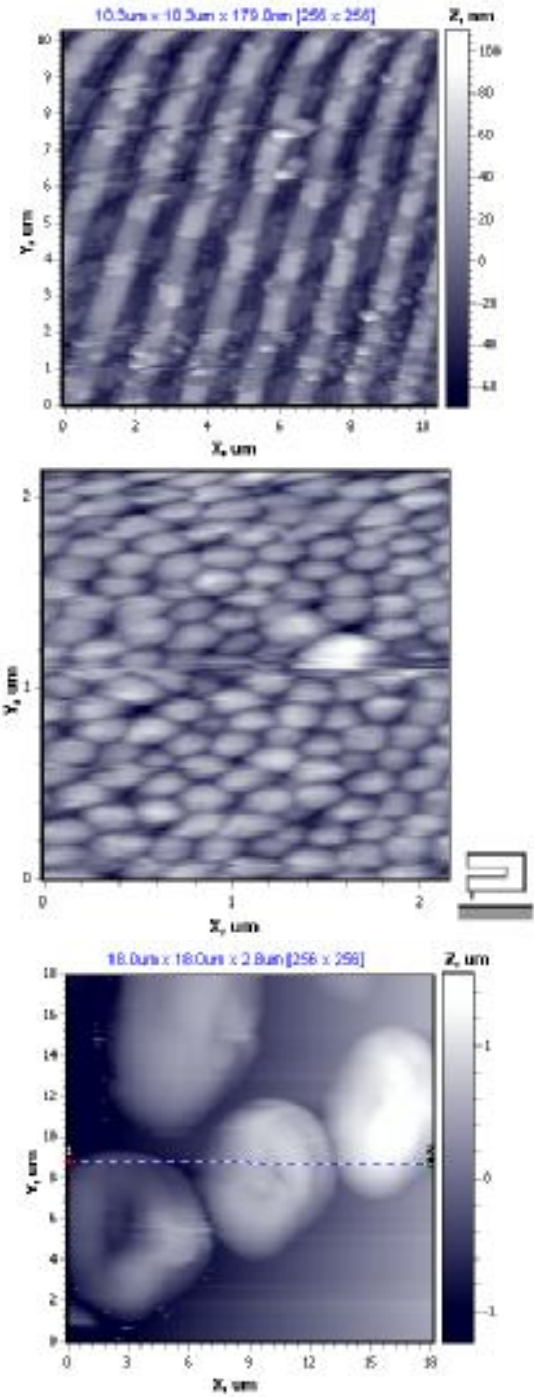

Рис. 4. Приклади розподілу сил тертя, отриманих динамічною силовою спектроскопію на неоднорідних діелектричних поверхнях

Ще одним прикладом застосування методу АСМ для досліджень механічних властивостей поверхні є осцилююча мікротрібометрія, яка дозволяє проводити дослідження на зношуваність окремих фаз і структурних утворень матеріалів (рис. 5), в результаті чого можна проводити аналіз тертя i зношення діелектричних поверхонь на мікро- і нанорівнях. Прикладні застосування цього методу відкривають широкі перспективи для його використання при дослідженні трибометричних характеристик діелектричних поверхонь.

Аналогом скануючої тунельної спектроскопії для АСМ є можливість отримувати залежності сили взаємодії зонда з поверхнею зразка від відстані між ними - так звані криві підведення чи відведення. 

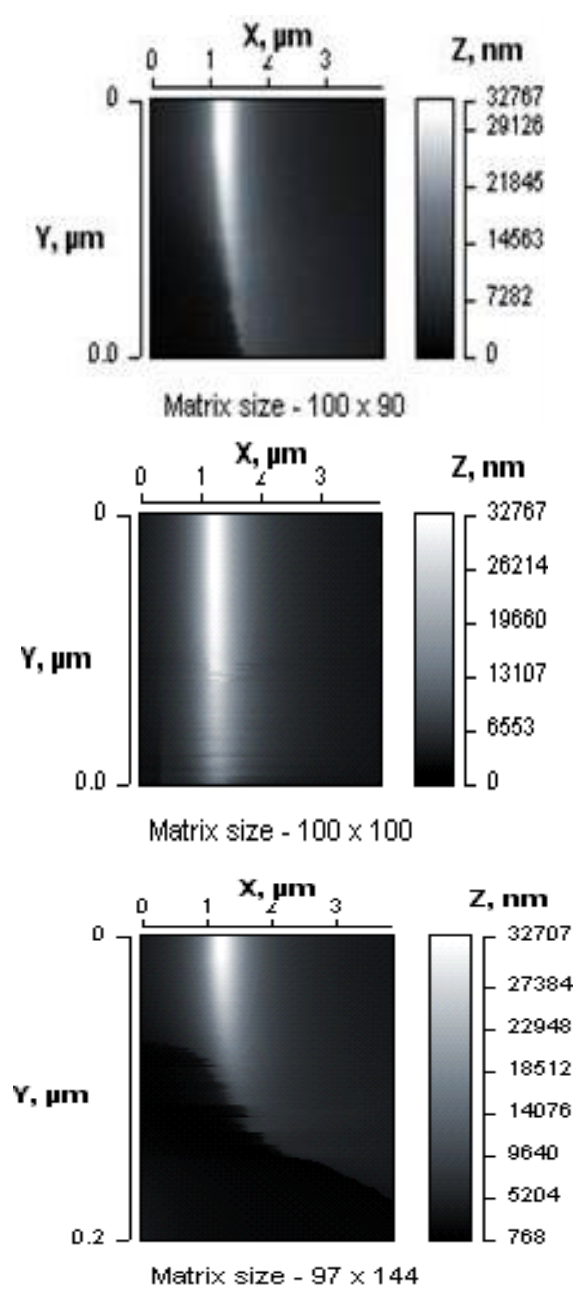

Рис. 5. Карта амплітудно-частотної візуалізації процесу тертя зонда АСМ по поверхні кремнісвої пластини до очищення (вгорі), після хімічного травлення (в центрі) та після очищення i подальшого змащування (знизу)

(метод осцилюючої мікротрибометрії)

Ці криві важливі для вимірювання вертикальної сили, що прикладається до поверхні 3 боку вістря в процесі сканування. Крім того, аналізуючи зміни форми цієї кривої, можна оцінювати в'язкість забруднення поверхні, товщину в'язкого шару різних рідин, адсорбованих на поверхні діелектрика, а також місцеві варіації пружних властивостей поверхні.

Серед методик проведення механічних вимірювань слід виділити метод наноіндентування як такий, що $з$ досить високою точністю дозволяе отримувати інформацію про нанотвердість окремих нанометричних ділянок досліджуваної поверхні. Наноіндентування проводиться шляхом аналізу механічного відгуку поверхні зразка на вдавлювання наносенсорів ACM (рис. 6).
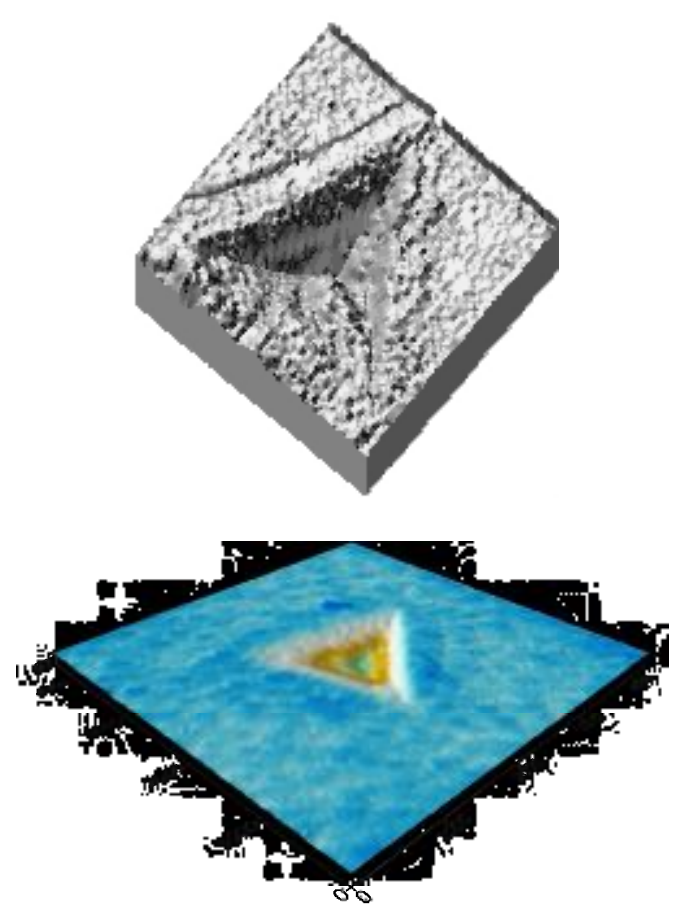

Рис. 6. АСМ-зображення відбитка наноіндентора на кремнії

Наноіндентування діелектричної поверхні 3 метою визначення іiі нанотвердості найбільш широко розвинений і часто вживаний метод досліджень фізико-механічних властивостей поверхонь діелектриків, що проводиться з використанням АСМ. За допомогою цього методу можна визначити не лише нанотвердість поверхні, але й ії модуль пружності, при цьому точність його визначення становить 10-15\%, що є досить високим значенням при визначенні модуля Юнга.

Обмеження методу АСМ при механічних вимірюваннях поверхні пов'язані з труднощами при розшифруванні одержуваної в експериментах інформації, необхідністю вибору і побудови математичної моделі механічної взаємодії, а також не досить високою точністю проведення аналізу. Також обмеження методу пов'язані 3 необхідністю використання спеціальних зондів, які вимагають юстування після кожного циклу сканування.

Слід відзначити, що, наприклад, методом осцилюючої мікротрибометрії можна отримувати лише якісні характеристики, а отримання кількісних характеристик можливе лише шляхом порівняння коефіцієнтів тертя між досліджуваною поверхнею і еталонною поверхнею з відомим коефіцієнтом тертя. 
Дослідження електричних і магнітних властивостей поверхні. Контактна електросилова мікроскопія може бути реалізована на базі методу АСМ i, як правило, використовується для дослідження напівпровідникових структур [5]. При цьому зображення магнітного або електричного поля можна отримати при двократному скануванні досліджуваної поверхні в напівконтактному режимі. За перший прохід сканується топографія поверхні, у другий прохід зонд рухається, повторюючи профіль поверхні, але на певній відстані від неї. Для отримання поля розподілу поверхневих зарядів можна використовувати контактний режим роботи АСМ. У цьому режимі на консоль подається зсув $U_{t i p}=U_{d c}+U_{a c} \sin (\omega t)$, де $U_{a c}$ - напруга збудження коливань.

Сканування проводиться в режимі постійної сили з одночасним вимірюванням електричних сил. Смнісна сила $F_{c a p}(z)$ між зондом і поверхнею, що знаходиться при потенціалі $U_{s}$, дорівнюе $F_{\text {cap }}(z)=\frac{1}{2}\left(U_{t i p}-U_{s}\right)^{2} \frac{d C}{d z}$, де $C(z)$ $\epsilon$ ємністю конденсаторної системи «зондповерхня», що залежить від геометрії зонда, рельєфу поверхні і відстані зонд-поверхня. В контактній електросиловій мікроскопії реєструється вплив першої гармоніки $F_{c a p}(z)$ на коливання консолі.

Серед обмежень методу АСМ при дослідженні електричних і магнітних властивостей поверхні треба відзначити наступне. Якість дослідження залежить від якості провідного покриття на зонді: забруднена поверхня і ненадійний електричний контакт, а також знос провідного покриття на зонді та утворення оксидного шару на ньому при контакті 3 досліджуваною поверхнею призводять до значного погіршення якості і точності одержуваного результату, а також до виникнення артефактів зображення.

Висновки. В статті проведено огляд особливостей дослідження мікрогеометрії і поверхневих властивостей діелектричних матеріалів для мікро- і наноелектроніки методом атомно-силової мікроскопії, а також переваг і обмежень використання останнього для дослідження діелектричних матеріалів для мікро- та наноелектроніки.

Проведений аналіз літературних та інформаційних джерел показав відсутність універсального неруйнівного методу дослідження стану поверхні та іiі фізико-механічних властивостей. У той же час серед існуючих методів дослідження поверхні найбільш прогресивним і універсальним виступає метод атомно-силової мікроскопії, який не вимагає спеціальної підготовки досліджуваного зразка, $є$ неруйнівним, має високу точність (до одиниць ангстрем), чутливість дослідження $\left(\approx 10^{-8} \mathrm{H}\right)$, а також має високу продуктивність та оперативність дослідження.

Розглянуто основні напрямки досліджень топограм, механічних і електромагнітних властивостей поверхонь діелектриків, які проводяться за допомогою методу атомносилової мікроскопії, а також встановлено обмеження і недоліки при використанні цього методу для дослідження окремих властивостей діелектричних поверхонь.

Подальший розвиток цього методу полягає у реалізації ряду методик і пристроїв на базі обладнання для атомно-силової мікроскопії, наприклад: визначення просторової молекулярної структури речовини, що дозволяє не тільки відновити хімічний склад і формулу речовини, але й її просторову орієнтацію, а також створення струминного 3Dнанопринтера, що дав би змогу створювати високоточні наноструктури на основі кремнію та інших напівпровідників, проводити точкове проникнення домішкових атомів для створення квантових точок, міток, а також атомарних -p-n-p-переходів.

Як інструментальний розвиток методу АCM перспективною $є$ реалізація інструментів нанодрель і нановеретено, що дозволять створювати в поверхнях діелектриків мікро- i наноотвори, формувати структурні утворення, одержувати нитки 3 вуглецевих нанотрубок, проводити механоактивацію поверхневих шарів діелектриків наносвердленням.

Ще одна 3 перспектив розвитку - метод наноштампування полімерного шару, який дозволить створювати полімерні надструктури безпосередньо на поверхнях зразківзапалів, що виключає необхідність використання важких, дорогих i тривалих методів отримання полімерних наноструктур, як, наприклад, метод Ленгмюр-Блоджетт.

\section{Список літератури}

1. Суслов А. А., Чижик С. А. Сканирующая зондовая микроскопия. Материаль, технологии, инструментыл. 1997. № 3. С. 78. 
2. Чижик С. А., Свириденок А. П., Суслов А. А. Глаза и руки нанотехнологий. Наука и инновации. 2009. № 3. С. 53-55.

3. Антонюк В. С., Тимчик Г. С., Бондаренко Ю. Ю. та ін. Методи та засоби мікроскопії. Київ: НТУУ «КПІ», 2013. 336 с.

4. Антонюк В. С., Тимчик Г. С., Верцанова О. В. та ін. Мікроскопія в нанотехнологіях. Київ: НТУУ «КПІ», 2014. 258 с.

5. Бардин В. А., Васильев В. А., Чернов П. С. Принципы построения и перспективы исследований пьезоактюаторов для нано- и микропозиционирования. $\mathrm{Ha}$ но- и микросистемная техника. Москва: Новые технологии, 2015. № 1. С. 90-93.

6. Meyer, E. Atomic force microscopy. Progress in Surface Science. 1992, vol. 41, iss. 1. P. 3-49.

7. Миронов В. Л. Основы сканирующей зондовой микроскопии. Н. Новгород: Инт физики микроструктур РАН, 2004. 143 с.

8. Binnig G., Quate C. F., Gerber C. Atomic force microscope. Phys. Rev. Lett. 1984, vol. 56. P. 930-933.

9. Giessibl F.J. Advances in atomic force microscopy. Reviews of modern physics. 2003, vol. 75. P. 949-983.

10. Jalili N., Laxminarayana K. A review of atomic force microscopy imaging systems: application to molecular metrology and biological sciences. Mechatronics. 2004, vol.14. P. 907-945.

11. Magonov S. N., Myung-Hwan Whangbo Dr. Surface analysis with STM and AFM: Experimental and theoretical aspects of image analysis. Oxford, UK: Wiley. September 2008. 335 p.

12. Boisen A. AFM probes with directly fabricated tips. Journal of Micromechanics and Microengineering. 1996, vol. 6, iss. 1. P. 58-62.

13. NT-MDT. URL: http://www.ntmdttips.com/catalog/gratings/ afm_cal/products.html (21.01.2017).

14. Ash $\bar{h}$ ab M. Dynamical analysis and control of microcantilevers. Automatica. 1999, vol. 35 , iss. 10. P. 1663-1670.

15. Liu H. Advanced atomic force microscopy probes: Wear resistant designs. Journal of Vacuum Science \& Technology B. 2005, vol. 23. P. 3090-3093.

16. Бахтизин Р. З., Галлямов Р. Р. Физические основы сканирующей зондовой микроскопии. Уфа: РИО Баш. ГУ, 2003. 82 с.
17. Cappella B., Dieller G.Force-distance curves by atomic microscopy. Surface Sci. Rep. 1999, v. 34. P. 1-12.

18. Fleming A. J. A review of nanometer resolution position sensors: Operation and performance. Sensors and Actuators A. 2013. № 190. P. 106-126.

19. Persson B. N. J. Sliding friction: physical principles and applications. Berlin: Springer, 1998.

\section{References}

1. Suslov, A. A., Chizhik S. A. (1997) Scanning probe microscopy. Materials, technologies, tools, iss. 3, p. 78 [in Russian].

2. Chizhik, S. A., Sviridyenok, A. P., Suslov A. A. (2009) The eyes and arms of nanotechnology. Science and Innovation, iss. 3, pp. 53-55 [in Russian].

3. Antonyuk, V. S., $\quad$ Tymchyk, G. S., Bondarenko, Yu. Yu. et al. (2013) Methods and means of microscopy. Kyiv: NTUU «KPI», 336 p. [in Ukrainian].

4. Antonyuk, V. S., Tymchyk, G. S., Vercanova, O. V. et al. (2014) Microscopy in nanotechnology. Kyiv: NTUU «KPI». 258 p. [in Ukrainian].

5. Bardin, V. A. Vasil'ev, V. A., Chernov, P. S. (2015) Principles of construction and prospects for studies of piezo actuators for nano- and micropositioning. Nano- and microsystem technology. Moskow: New technologies, iss.1, pp. 90-93 [in Russian].

6. Meyer, E. (1992) Atomic force microscopy. Progress in Surface Science, vol. 41, iss. 1, pp. 3-49.

7. Mironov, V. L. (2004) Basics of scanning probe microscopy. N. Novgorod: Institute of Physics of Microstructures of RAS, $143 \mathrm{p}$. [in Russian].

8. Binnig, G. Quate, C. F. and Gerber, C. (1984) Atomic force microscope. Phys. Rev. Lett., vol. 56, pp. 930-933.

9. Giessibl, F. J. (2003) Advances in atomic force microscopy. Reviews of modern physics. vol. 75, pp. 949-983.

10. Jalili, N. and Laxminarayana, K. (2004) A review of atomic force microscopy imaging systems: application to molecular metrology and biological sciences. Mechatronics, vol.14, pp. 907-945.

11. Magonov, S. N. and Myung-Hwan Whangbo, Dr. (2008) Surface analysis with 
STM and AFM: Experimental and theoretical aspects of image analysis. Oxford, UK: Wiley. September, 335 p.

12. Boisen, A. (1996) AFM probes with directly fabricated tips. Journal of Micromechanics and Microengineering, vol. 6, iss. 1, pp. 58-62.

13. NT-MDT. URL: http://www.ntmdttips.com/catalog/gratings/ afm_cal/products.html (21.01.2017).

14. Ashhab, M. (1999) Dynamical analysis and control of microcantilevers. Automatica, $\mathrm{vol} / 35$, iss. 10, pp. 1663-1670.

15. Liu, H. (2005) Advanced atomic force microscopy probes: Wear resistant designs.
Journal of Vacuum Science \& Technology B., vol. 23. pp. 3090-3093.

16. Bahtizin, R. Z. Galyamova, R. R. (2003) Physical basis of scanning probe microscopy. Ufa: BashSU. 82 p. [in Russian].

17. Cappella, B., Dieller, G. (1999) Forcedistance curves by atomic microscopy. Surface Sci. Rep., v. 34, pp. 1-12.

18. Fleming, A. J. (2013) A review of nanometer resolution position sensors: Operation and performance. Sensors and Actuators A, № 190, pp. 106-126.

19. Persson, B. N. J. (1998) Sliding friction: physical principles and applications. Berlin: Springer.

S. F. Petrenko ${ }^{1}$, D.Sc., professor

Research and production complex "Lileya", Kyiv, Ukraine

A. G. Novakovskii ${ }^{1}$,

V. S. Antoniuk ${ }^{1}, D . S c$., professor

E. V. Skorina ${ }^{2}$,

Yu. Yu. Bondarenko ${ }^{2}$, Ph.D., associate professor

${ }^{1}$ National Technical University of Ukraine "Igor Sikorsky Kiev Polytechnic Institute"

Peremohy ave., 37, Kyiv, 03056, Ukraine

${ }^{2}$ Cherkasy State Technological University

Shevchenko blvd, 460, Cherkasy,18006, Ukraine

\section{FEATURES OF MICROGEOMETRY RESPONSE AND SURFACE PROPERTIES OF DIELECTRIC MATERIALS FOR MICRO- AND NANOELECTRONICS}

The article briefly describes the principle and operating modes of atomic-force microscope (AFM), as well as the features of microgeometry and surface properties of dielectric materials for micro and nanoelectronics using AFM method. The purpose of this article is to determine the features of microgeometry research and surface properties of dielectric materials by atomic force microscopy, as well as the advantages and limitations of the use of this method in the investigation of dielectric materials. The advantages and limitations of the application of this method for surface and surface properties of dielectrics are shown. The main directions of study of topographies, mechanical and electromagnetic properties of surfaces of dielectrics, which are carried out with the help of atomicforce microscopy method, as well as limitations and drawbacks in the use of this method in the investigation of individual properties of dielectric surfaces are also considered. The further development of this method consists in the implementation of a number of techniques and devices based on equipment for atomic-force microscopy. Perspective instrumental methods with the use of AFM show the implementation of nanodrill and nanorethene instruments, allowing the creation of micro and nanoelectric dielectrics in surfaces, forming structural formations, obtaining threads from carbon nanotubes, conducting mechanoactivation of surface layers of dielectrics by nanoparticle.

Key words: microgeometry, dielectric material, microelectronics, nanoelectronics, atomic-force microscopy.

Стаття надійшла 06.03.2018.

Статтю представляє В. С. Антонюк, д.т.н., професор. 